\title{
ANALISIS DAYA SAING GABUNGAN KELOMPOK TANI (GAPOKTAN) LADA HITAM DI KABUPATEN LAMPUNG UTARA
}

\author{
Nurul Husna ${ }^{1)}$ \\ email: nuyhusna29@gmail.com@gmail.com \\ 1) Manajemen, Universitas Teknokrat Indonesia \\ Jl. H.ZA Pagaralam, No 9-11, Labuhanratu,Bandarlampung \\ Email :pertama@gmail.com ${ }^{1)}$,kedua@ymail.com ${ }^{2}$, ketiga@teknokrat.ac.id ${ }^{3)}$
}

\begin{abstract}
Abstrak
Penelitian ini bertujuan untuk mengetahui faktor-faktor yang menentukan daya saing (Gabungan Kelompok Tani) lada hitam di Kabupaten Lampung Utara. variabel daya saing dihitung dari tiga dimensi yaitu biaya
\end{abstract}

Kata kunci: Total Pendapatan Daerah, Pajak Daerah dan Pertumbuhan Ekonomi.

\section{Pendahuluan}

\subsection{Latar Belakang}

Lada (Piper nigrum L) merupakan salah satu komoditas subsektor perkebunan yang telah memberikan kontribusi nyata sebagai sumber devisa, penyedia lapangan kerja, dan sumber pendapatan petani. Indonesia merupakan produsen dan eksportir utama lada di dunia.

Indonesia sudah lama dikenal sebagai produsen utama lada dunia, terutama lada hitam (Lampung Black Pepper) yang dihasilkan di Provinsi Lampung dan lada putih (Muntok White Pepper) yang berasal dari Provinsi Kepulauan Bangka Belitung. Indonesia merupakan produsen dan eksportir utama lada di dunia. Produksi lada putih Indonesia mencapai sekitar $80 \%$ pasokan dunia sedangkan untuk produksi lada hitam hanya mencapai $15 \%$ pasokan dunia.

Gabungan kelompok tani (Gapoktan) Kabupaten Lampung Utara adalah produsen terbesar lada hitam untuk pemenuhan permintaan ekspor dunia. Terdapat 80 jumlah Gapoktan di Kabupaten Lampung Utara yang tersebar di 23 Kecamatan. Gapoktan yang berjumlah 80 tersebut memasok lada hitam baik ke pasar domestik maupun pasar ekspor secara kontinyu, namun adanya beberapa kendala menyebabkan Gapoktan mengalami kesulitan untuk memenuhi permintaan pasar ekspor.Berdasarkan fenomena-fenomena yang telah diuraikan di atas, maka peneliti bermaksud melakukan penelitian yang berjudul "Analisis Daya Saing Gabungan Kelompok Tani (Gapoktan) Lada Hitam di Kabupaten Lampung Utara", untuk mengetahui gambaran mengenai pencapaian daya saing pada Gapoktan Lada Hitam di Kabupaten Lampung Utara.

\section{Pembahasan}

Penelitian ini merupakan jenis penelitian deskriptif karena penelitian ini bertujuan untuk memberikan gambaran terhadap variabel. Penelitian deskriptif yaitu penelitian yang dilakukan terhadap variabel mandiri (variabel berdiri sendiri) bertujuan untuk memberi gambaran mengenai kondisi strategi bersaing pada Gabungan Kelompok Tani (Gapoktan) Lada Hitam di Kabupaten Lampung Utara tanpa membuat perbandingan atau menghubungkan dengan variabel lain dan sampel lain.

Teknik pengumpulan data yang akan dipakai oleh peneliti, yaitu studi lapangan. Pada studi lapangan, data dan informasi yang didapat dan dipakai bersifat primer. Dimana pada studi lapangan tahapan-tahapan yang akan dilakukan yaitu melalui wawancara dan kuesioner.Populasi dalam penelitian ini adalah seluruh Gapoktan Lada Hitam yang aktif di Kabupaten Lampung Utara Provinsi Lampung yang berjumlah 80 gapoktan. Dalam penelitian ini tidak digunakan teknik sampling karena sampel yang diteliti adalah keseluruhan dari populasi yang ada atau disebut sensus. Mengingat jumlah populasi hanya sebesar 80 Gapoktan, maka layak untuk diambil keseluruhan untuk dijadikan sampel tanpa harus mengambil sampel dalam jumlah tertentu. Sehingga sampel dari penelitian ini adalah seluruh Gapoktan Lada Hitam yang ada pada Kabupaten Lampung Utara.

\subsection{Dimensi Cost Leadership}

Perusahaan yang menggunakan strategi cost leadership memiliki tujuan untuk mencapai pangsa pasar yang lebih besar yang didasarkan pada harga yang lebih rendah.

Berdasarkan pengamatan yang dilakukan, persediaan lada hitam di gudang Gapoktan memang cukup banyak, terbukti bahwa lada hitam di Kabupaten Lampung Utara memproduksi lada hitam yang paling besar di provinsi Lampung. Akan tetapi, lada hitam di Kabupaten Lampung Utara tidak memiliki kualitas yang lebih bagus dibandingkan dengan lada hitam Kabupaten Lampung Timur, terbukti bahwa indikator pengendalian kualitas memiliki nilai yang paling rendah pada dimensi cost leadership, yaitu sebesar 3,0250. Gapoktan kurang ikut andil dalam meningkatkan kualitas produk lada hitam yang dihasilkan petani, mereka tidak pernah mengajarkan para petaninya, dan mengundang para ahli di bidang pertanian untuk memberitahu kepada para petaninya bagaimana membudidayakan lada secara berkualitas. Terbukti ekspor lada hitam terbesar di Provinsi Lampung ada pada Kabupaten Lampung Timur. Pada tahun 2015, Kabupaten Lampung Timur berhasil 
mengekspor lada hitam sebesar $80 \%$ dari hasil produksinya (sesuai dengan ketentuan Kementrian Pertanianbahwa seharusnya ekspor lada hitam Indonesia yaitu $80 \%$ dari jumlah setiap produksi lada hitam.), sedangkan lada hitam untuk Kabupaten Lampung Utara hanya berhasil mengekspor lada hitam-nya sebesar $43 \%$ dari hasil produksinya, padahal produksi lada hitam terbesar ada pada Kabupaten Lampung Utara sedangkan Kabupaten Lampung Timur adalah Kabupaten penghasil lada nomor 3 di Provinsi Lampung.Kabupaten Lampung Timur menjadi pemasok terbesar lada hitam untuk dunia. Pada bulan juli tahun 2016 yang lalu, mereka mendapatkan penghargaan dari istana negara sebagai kualitas lada hitam terbaik di dunia.

\subsection{Dimensi Differentiation}

Strategy Differentiation dapat dicapai oleh perusahaan melalui pengembangan produk atau jasa sehingga memiliki karakteristik seperti yang diinginkan oleh konsumen, yang memungkinkan perusahaan untuk dapat memberikan harga yang tinggi sesuai dengan nilai yang diberikan kepada konsumen (Asdemir et. al, 2013).

Strategi bersaing dimensi differentiation yang diformulasikan, diukur berdasarkan kemampuan perusahaan dalam memperkenalkan produk baru, kemampuan perusahaan dalam berinovasi, kemampuan perusahaan dalam pengembangan produk baru, dan kemampuan perusahaan untuk membedakan diri dibandingkan pesaing.

Berdasarkan hasil pengamatan dan wawancara yang dilakukan, Gapoktan dalam memperkenalkan produk barunya melalui facebook. Facebook Gapoktan berteman dengan para pelanggan tetap mereka, sehingga jika mereka mempunyai produk baru mereka memposting lewat dinding facebook mereka dan dapat langsung dibaca oleh para pelanggannya. Selanjutnya, Gapoktan di Kabupaten Lampung Utara juga memiliki inovasi produk pada lada hitamnya, Gapoktan menerima pesanan bagi para pelanggan yang menginginkan bubuk lada hitam. Beberapa Gapoktan lada hitam di Kabupaten Lampung Utara sudah memiliki alat penggilingan untuk membuat bubuk lada hitam, sehingga jika ada permintaan untuk bubuk lada hitam kualitas apapun, mereka dapat melayaninya.

Selanjutnya, indikator kemampuan perusahaan dalam pengembangan produk baru dan kemampuan perusahaan membedakan diri dibandingkan pesaing berada dalam rentang penilaan sedang, yaitu sebesar 3,2. Dalam membudidayakan lada hitam, Kabupaten Lampung Utara tidak melakukan pengembangan dan ciri khas dibandingkan pesaing mereka. Berbeda dengan yang dilakukan Kabupaten Lampung Timur, mereka membudidayakan ladanya secara organik. Maka dari itu, hasil lada hitam lebih dikenal dari Kabupaten Lampung Timur dibandingkan Kabupaten Lampung Utara, padahal sentra produksi lada hitam di Provinsi Lampung adalah Kabupaten Lampung Utara.

\subsection{Dimensi Quick Response}

Heizer mendefinisikan respon sebagai keseluruhan nilai yang terkait dengan pengembangan dan pengantaran barang yang tepat waktu, penjadwalan yang dapat diandalkan, dan kinerja yang fleksibel.

Strategi Bersaing dimensi quick response yang diformulasikan, diukur berdasar pada pengantaran barang, penjadwalan pengiriman barang, dan kemampuan untuk memenuhi perubahan pasar. Gapoktan dalam mengantarkan barang kepada pelanggan cukup tepat waktu dan sesuai dengan yang dijadwalkan, kemudian untuk mengantisipasi perubahan yang terjadi di pasar cukup baik.

Berdasarkan hasil pengamatan, para Gapoktan kurang memikirkan apa yang diinginkan pasar dimasa depan, mereka hanya fokus untuk mengumpulkan lada hitam yang telah dihasilkan para petani dan mensortirnya, tidak memikirkan untuk mengembangkan produk lada hitamnya sesuai dengan perkembangan permintaan lada hitam sekarang.

Tabel 4.4 Rekapitulasi Skor Presentase Tanggapan Untuk Strategi Bersaing

\begin{tabular}{|r|l|r|l|l|}
\hline No & Dimensi & $\begin{array}{l}\text { Skor } \\
\text { Aktual }\end{array}$ & $\begin{array}{l}\text { Rata- } \\
\text { rata }\end{array}$ & Kategori \\
\hline 1 & $\begin{array}{l}\text { Cost } \\
\text { leadership }\end{array}$ & 256 & 3,20 & Sedang \\
\hline 2 & Differentiation & 266 & 3,3250 & Sedang \\
\hline 3 & $\begin{array}{l}\text { Quick } \\
\text { Response }\end{array}$ & 247 & 3,0875 & Sedang \\
\hline \multicolumn{2}{|c|}{ Total } & $\mathbf{7 6 9}$ & $\mathbf{3 , 2 0 4 1}$ & Sedang \\
\hline
\end{tabular}

Sumber: Data diolah, 2017

\section{Kesimpulan}

Berdasarkan hasil penelitian, pencapaian daya saing pada Gapoktan lada hitam di Kabupaten Lampung Utara sudah cukup tepat, tetapi perlu diperhatikan pengendalian kualitas lada hitam dan kemampuan untuk memenuhi perubahan pasar, diharapkan Gapoktan lebih memperhatikan kualitas produk lada hitam yang dihasilkan oleh para petaninya sehingga dapat meningkatkan daya saing lada hitam yang diproduksi oleh Gapoktan di Kabupaten Lampung Utara dan memenuhi perkembangan permintaan lada yang terjadi sekarang.

\section{Daftar Pustaka}

[1] Asdemir et al. 2013. Market perception of firm strategy. Managerial Finance, 39 (2).

[2] Chopra, Sunil \& Meindl, Peter. 2004. Supply Chain Management Strategy, Planning, and Operation. Second Edition.

[3] Duran, Cengiz \& Akci, Yavuz. 2015. Impact of Competitive Strategies and Supply Chain Strategies on The Firm Performance Under Environmental Uncertainties. International Journal of Economics, Commerce and management. Vol. III. Issue 1. 
[4] Grant, Robert M.. 1997. Diterjemahkan oleh Thomas Secokusomo. Analisis Strategi Kontemporer: Konsep, Teknik, Aplikasi. Jakarta: Erlangga.

[5] Heizer \& Render. 2009. Manajemen Operasi Buku 1 Edisi 9. Jakarta: Salemba 4.

[6] Jung, Joo Y. 2009. Competitive strategy, TQM practice, and continuous improvement of international project management A contingency study. International Journal of Quality \& Reliability Management. Vol. 26. No. 2.

[7] Kotler, Philip. 2001. Manajemen Pemasaran: Analisis, Perencanaan, Implementasi, dan Kontrol. Jakarta : PT. Prehallindo.

[8] Leli Nuryati, Noviati. 2015. Outlook Lada Komoditas Pertanian Subsektor Perkebunan. Pusat Data dan Sistem Informasi Pertanian Sekretariat Jenderal-Kementrian Pertanian.

[9] Porter, Michael E. 1995. Strategi bersaing tehnik menganalisis industri dan pesaing. Jakarta:Erlangga.

[10]Pulaj, Enida. et al. 2015. The Impact of Generic Competitie Strategies on Organizational Performance. The Evidence From Albanian Context. European Scientific Journal. Vol. 11. No. 28.

[11] Suhartati, Titi \& Rosietta, Hilda. 2012. Pengaruh Strategi Bersaing Terhadap Hubungan Antara Supply Chain Management dan Kinerja (Studi Pada Perusahaan Manufaktur yang Terdaftar di BEI). 